\title{
PENERAPAN MODEL PROBLEM BASED LEARNING DALAM MENINGKATKAN KREATIVITAS MATEMATIS SISWA PADA MATERI BILANGAN BULAT
}

\author{
Nursita Hi. Mannan'1, Idrus Alhaddad², Ikram Hamid ${ }^{3}$ \\ ${ }^{1,2,3}$ Program Studi Pendidikan Matematika, Universitas Khairun
}

\begin{abstract}
ABSTRAK
Penelitian tindakan kelas ini bertujuan dalammeningkatkan kreativitas matematis siswa pada materi operasi bilangan bulatpada siswa kelas VII ${ }^{\mathrm{C}}$ SMP Muhammadiyah 1 Kota Ternate melalui model problem based learning. Teknik pengumpulan data dalam penelitian ini adalah dengan menggunakan teknik tes dalam bentuk soal uraian yang berjumlah 4 soal. Data yang dikumpulkan kemudian dianalisis dengan menggunakan pedoman Tingkat Penguasan (TP) dan untuk mengatahui penigkatan hasil belajar siswa digunakan rumus $N$. Gain $(g)$. Pada tes siklus I, kemampuan siswa diperoleh 5 siswa $(21,73 \%)$ interpretasi tinggi dan 18 siswa $(78,26 \%)$ interpretasi rendah. Siswa yang tuntas belajar secara individu sebanyak 5 siswa Ketuntasan klasikal 21,73\%, sedangkan 18 siswa tidak tuntas secara klasikal adalah 78,26\% diperoleh skor rata-rata hasil belajar siswa 61,39 atau dilihat dari rumus $N$. Gain $(g)$. sama dengan 0,25. Hasil belajar siswa tes siklus I belum tuntas. Untuk hasil tes siklus II diperoleh sebanyak 12 siswa $(52,17 \%)$ interpretasi tinggi, Sedangkan sebanyak 10 siswa $(43,47 \%)$ interpretasi sedang, Rendah sebanyak 1 siswa $(4,34 \%)$. Siswa yang tuntas belajar secara individu sebanyak 23 siswa, sedangkan ketuntasan belajar klasikal 100\% diperoleh skor rata-rata hasil belajar siswa 87,43. Hasil belajar pada siklus II meningkat sebesar 0,67dari tes siklus I.
\end{abstract}

Kata Kunci :Problem Based Learning, Kreativitas Matematis, Operasi Bilangan Bulat.

\section{PENDAHULUAN}

Matematika merupakan mata pelajaran yang memiliki peranan yang sangat penting dalam kehidupan terutama di dalam dunia pendidikan, hal ini dikarenakan matematika bersifat logis dan dapat menjelaskan sebuah konsep secara ilmiah dan sering digunakan diberbagai cabang ilmu pengetahuan lain sehingga banyak cabang ilmu pengetahuan yang berhubungan dengan matematika baik secara langsung maupun tidak langsung. Pada saat ini pembelajaran matematika sering dianggap sebagai mata pelajaran yang sulit bagi siswa dan bahkan terkadang menjadi sebuah mata pelajaran yang tidak disukai oleh siswa karena sering dianggap sulit Rahman, (2015: 63-64). 
Berdasarkan dengan masalah di atas, maka guru matematika hendaknya menguasai kumpulan pengetahuan masa lalu yang kemudian diteruskan pada peserta didik dan juga menguasai proses, pendekatan dan metode matematika yang sesuai dapat mendukung peserta didik berfikir kritik, menggunakan nalar secara efektik dan efisien, serta menanamkan benih sikap ilmiah/disiplin, bertanggung jawab, keteladanan dan rasa percaya diri disertai dengan iman dan taqwa. Dengan bekal tersebut diharapkan peserta didik memiliki kemampuan menghadapi masa yang akan datang selalu berubah, dan menjadi manusia yang berkualitas yang diperlukan untuk pembangunan bangsa.

Berdasarkan hasil observasi pada tanggal 14Agustus 2016-21 Agustus 2016 di SMP Muhammadiyah 1 Kota Ternate ketuntasan belajarnya masih rendah dan banyak yang remedial dan setelah dilakukan diskusi dengan gurunya, ternyata didapatkan informasi bahwa pembelajaran yang selama ini diterapkan di SMP Muhahammdiyah 1 Kota Ternate, pada umumnya adalah pembelajaran yang sifatnya langsung dimana siswa bekerja secara individual. Apabila dalam menyelesaikan masalah terkadang mereka tidak mampu mengatasi masalah tersebut.Oleh karena itu, untuk membantu agar siswa tidak larut dalam masalah maka peneliti mengambil sebuah tindakan yang dianggap dapat membantu siswa keluar dari masalah tersebut.

Adapun kondisi yang terjadi pada kelas VII $^{\mathrm{C}}$ saat peneliti melakukan observasi yaitu sebagai berikut:

1. Siswa lebih banyak kerja sama dengan temannya saat guru memberikan tugas di kelas.

2. Saat diskusi siswa terlihat pasif dan guru lebih banyak berperan aktif.

3. Siswa tidak mengeluarkan pendapat sendiri tetapi saling ketergantungan kepada temannya.

4. Siswa tidak bisa menyelesaikan masalah pada saat pembelajaran berlangsung. Model pembelajaran yang digunakan adalah model pembelajaran konvensional yaitu pembelajaran yang didominasi oleh guru, siswa hanya duduk mendengarkan, meniru pola-pola yang diberikan guru, mencontohkan cara-cara guru menyelesaikan soal-soal yang pada akhirnya dapat membuat siswa menjadi pasif dan merasa kesulitan jika dihadapkan pada item-item yang bervariasi. 
Berdasarkan hasil observasi peneliti pada point 1,2, 3 dan 4 menunjukan bahwa tingkat kreativitas siswa masih rendah, rendahnya tersebut terjadi karena guru lebih dominan menggunakan model pembelajaran konvensional yang mengutamakan keaktifan guru dalam belajar, sehingga siswa kurang aktif dalam proses belajar mengajar. Adapun salah satu hasil kerja siswa saat peneliti memberikan soal dengan mengacu pada indikator kreativitas matematis yaitu 1), kelancaran dan 2) kelewesan, maka dilihat diagram siswa yang tuntas dan tidak tuntas sebagai berikut:

\section{Gambar}

\section{Grafik hasil siswa}

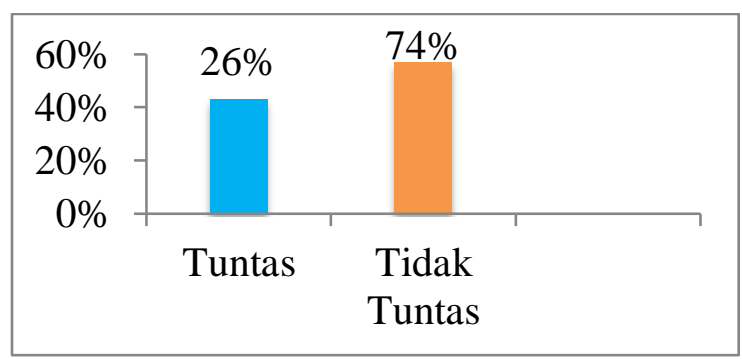

Berdasarkan diagram di atas dapat dilihat bahwa untuk materi penjumlahan dan pengurangan dengan menggunakan garis bilangan dan sifat-sifat penjumlahan dan pengurangan, terlihat bahwa terdapat $26 \%$ siswa yang tuntas dan sebanyak $74 \%$ siswa yang tidak tuntas. Penyelesaian yang tertera di atas menunjukan kreativitas siswa dalam menyelesaikan soal masih minim karena dalam soal tersebut belum terlihat jawaban siswa yang sesuai, siswa belum bisa bagaimana menyelesaikan masalah yang diberikan dalam soal tersebut.

Masalah yang terjadi di atas siswa belum memahami pernyataan yang diberikan dalam penyelesaian soal, siswa belum menghasilkan banyak gagasan dalam soal yang diberikan, dan juga siswa masih lambat dalam menyelesaikan soal yang menggunakan rumus diberikan. Hal ini yang menjadi perhatian dalam kreativitas siswa karena dapat berpengaruh dalam prestasi belajar siswa, kreativitas siswa itu sangat penting dalam proses belajar mengajar di sekolah itu dapat mengembangkan kemampuan berpikir tingkat tinggi siswa dan mempunyai kemampuan untuk menyelesaikanmasalah secara kreatif.

Model pembelajaran berbasis masalah mampu meningkatkan kemampuan berpikir kritis dan kreatif siswa lebih baik dibandingkan model pembelajaran langsung 
berdasarkan pendapat para ahli yaitu, Sanjaya (Sunaryo, 2014: 43), bahwa strategi pembelajaran berbasis masalah dapat diartikan sebagai rangkaian aktivitas pembelajaran yang menekankan kepada proses penyelesaian masalah yang dihadapi secara ilmiah.

\section{METODE PENELITIAN}

Penelitian ini menggunakan Penelitian Tindakan Kelas (PTK) di Kelas VII SMP Muhammadiyah 1 Kota Ternate. Penelitian ini dilaksanakan dalam 2 siklus. Setiap siklus yang mencakup 4 tahap yaitu perencanaan (planning), pelaksanaan tindakan (action), pengamatan (observation), dan evaluasi refleksi (reflection). Sementara desain penelitian

\section{Siklus I}

1. Tahap perencanaan

Pada tahap perencanaan mencakup semua langkah tindakan secara rinci.Segala keperluan pelaksanaan tindakan mulai dari materi bahan ajar, rencana pembelajaran yang mengacu pada metode/teknik mengajar serta teknik dan instrumen observasi/evaluasi dipersiapkan dengan matang pada tahap perencanaan. Kegiatan yang akan dilaksanakan pada tahap perencanaan adalah menyusun perangkat dalam pembelajaran yang terdiri dari:

a. Bahan ajar.

b. Rencana pelaksanaan pembelajaran (RPP).

c. Lembaran observasi

2. Tahap pelaksanaan tindakan

Dalam pelaksanaan tindakan, peneliti melakukan kegiatan belajar mengajar sesuai dengan rencana yang telah disusun pada tahap perencanaan.Dalam pelaksanaan tahapan ini, guru berperan ganda yaitu sebagai praktisi (pelaksana pembelajaran sekaligus sebagai peneliti).Pada langkah ini juga peneliti melakukan tes awal pada siklus I.

\section{Tahap observasi}

Melakukan pengamatan terhadap aktivitas siswa selama mengikuti kegiatan belajar mengajar dengan menggunakan model pembelajaran berbasis masalah.

4. Tahap refleksi 
Pada langkah ini, peneliti menganalisis hasil tindakan pada siklus I, apakah telah berhasil atau belum, peneliti analisis ini dilakukan sebagai bahan pertimbangan jika pada siklus I belum berhasil, maka peneliti akan dilanjukan tindakan pada siklus II dengan tindakan yang sama pada siklus I. Teknik pengumpulan data yaitu melalui tes, lembar Observasi, dan dokumentasi. Analisis data untuk menghitung tingkat penguasaan adalah $\mathrm{TP}=\frac{\text { jumlah skor yang diperoleh }}{\text { skor total }} \times 100 \%$. Sedangkan untuk mengetahui peningkatan kreativitas belajar siswa digunakan rumus N.Gain $(g)$ Ternormalisasi, Hake (Purnamasari, 2014: 12).

$$
N \cdot \operatorname{Gain}(g)=\frac{(\text { skorposttest })-(\text { skorpretest })}{(\text { skormaksimum }- \text { skorpretest })}
$$

\section{HASIL PENELITIAN}

Penelitian ini dikatakan berhasil jika terjadi peningkatan kreativitas matematis siswa yang dibuktikan dengan meningkatnya ketuntasan belajar secara individual dan klasikal (standar ketuntasan minimal 69). Sebelum peneliti menerapkan model pembelajaran berbasis masalah kepada siswa Kelas VII ${ }^{\mathrm{C}}$ SMP Muhammadiyah 1 Kota Ternate yang dijadikan subyek, terlebih dahulu peneliti diberikan tes awal pada hari kamis tanggal 5 Januari 2017 dengan memberikan 4 item soal untuk mengukur kreativitas matematis siswa terhadap materi operasi bilangan bulat.

\section{Paparan Proses dan Hasil Penelitian Pada siklus I \\ a. Tahap Perencanaan}

Setelah peneliti melakukan tes awal dan hasilnya telah diperoleh, selanjutnya peneliti melaksanakan pembelajaran dengan menggunakan model pembelajaran berbasis masalah (Problem basedlearning). Pada hari Saptu 7Januari 2017. Peneliti dan guru matematika mendiskusikan tentang RPP, LKS, metode mengajar, materi mengajar dan mempersiakan soal tes siklus I, lembar obsevasi dikuti dengan dokumentasi.

\section{b. Tahap pelaksanaan}

Pelaksanaan tindakan pada siklus I dilaksanakan pada hari Senin tanggal 9 Januari 2017. Peneliti melaksanakan proses belajar mengajar dengan menggunakan langkah-langkah model pembelajaran berbasis masalah (problem based learning). Adapun langkah-langkah sebagai berikut:

a) Orentasi siswa terhadap masalah 
b) Mengorganisasi siswa untuk belajar

c) Membimbing penyelidikan individual dan kelompok

d) Mengembangkan dan meghasilkan hasil karja

e) Menganalisis dan mengevaluasi proses pemecahan masalah

\section{a. Tahap Observasi}

Pada saat proses mengajar berlangsung, saat itu pula Observasipun berlangsung yang diamati oleh observer dengan mengisi lembar observasi kegiatan belajar mengajar. Pada siklus I peneliti menjelaskan materi tentang fungsi. Observer mengamati kegiatan tersebut, yaitu: keseriusan dalam mengikuti proses belajar mengajar, memperhatikan saat peneliti menjeleskan, keaaktifan siswa, berani mengajuhkan pertanyaan, menyelesaikan soal, dan menfasilitasi siswa untuk menyajikan hasil kerjanya masing-masing.

\section{b. Tahap Refleksi}

Setelah pelaksanaan tindakan siklus I, dilakukan evaluasi dengan cara memberikan tes kepada siswa yang terdiri dari 4 itemessay, hasil analisis data siklus I menggunakan tinggkat penguasaan menunjukkan bahwa 5 siswa $(21,73 \%)$ interpretasi tinggi, 18 siswa $(78,26 \%)$ interpretasi rendah. Selain itu berdasarkan KKM yang telah ditetapkan maka siswa yang tidak tuntas 18 siswa $(78,26 \%)$ sedangkan siswa yang tuntas 5 siswa $(21,73 \%)$. Nilai Gainnya adalah 0,30 yang diinterpretasikan sedang dengan nilai rata-rata siswa 62,5. dari hasil tes siklus I menunjukan bahwa secara keseluruhan hasil belajar siswa belum mencapai KKM yang telah ditetapkan oleh pihak sekolah, maka peneliti melanjutkan ke siklus II. Kelemahan dan kekurangan yang ada pada siklus I akan diperbaiki pada siklus II.

Hal-hal yang perlu dilakukan peneliti dalam memperbaiki kelemahan dan kekurangan pada siklus I adalah:

a) Harus memotivasi/membangkitkan minat siswa agar siswa bersemangat dalam belajar

b) Harus membahas hasil kerja kelompok setelah siswa melaksanakan pembelajaran kelompok, dalam hal ini menyelesaikan soal LKS

c) Harus memiliki kemampuan dalam pengelolaan kelas dengan baik. 


\section{Paparan Proses Hasil Penelitian Siklus II}

\section{a. Tahap Perencanaan}

Setelah peneliti melakukan tes siklus I dan hasilnya telah diperoleh sebagai acuan untuk melaksanakan model pembelajaran berbasis masalah(Problem based learning). Pada hari Kamis tanggal 12Januari 2017. Peneliti dan guru matematika mendiskusikan kembali tentang RPP, metode mengajar, materi mengajar dan soal tes siklus II.

\section{b. Tahap Pelaksanaan Tindakan}

Pelaksanaan tindakan pada siklus II dilaksanakan pada hari Saptu tanggal 14 Januari 2017, pembelajaran dilakukan sama dengan kegiatan belajar mengajar pada siklus I, yaitu menerapkan model pembelajaran berbasis masalah (Problem based learning), kemudian pada kegiatan ini ditambahkan soal-soal latihan untuk meningkatkan kemampuan dan pemahaman siswa dalam menyelesaikan soal pada materi operasi bilangan bulat.

\section{c. Tahap Observasi}

Setelah proses mengajar berlangsung, saat itu pula observasipun berlangsung yang diamati oleh observer dengan mengisi lembar observer kegiatan belajar mengajar.Pada siklus ini peneliti menjelaskan materi tentang operasi bilangan bulat. Observer mengamati kegiatan tersebut, yaitu: keseriusan dalam mengikuti proses belajar mengajar, memperhatikan saat guru menjelaskan, keaktifan siswa, berani mengajukan pertanyaan, menyelesaiakan soal, dan memfasilitasi siswa untuk menyajikan hasil kerjanya masing- masing.

\section{d. Tahap Refleksi}

Setelah tindakan siklus II, peneliti memberikan evaluasi siklus II untuk mengukur kemampuan siswa setelah diterapkan model pembelajaran berbasis masalah (Problem based learning)dan hasilnya dianalisis mengguankan rumus N. Gain Ternomalisasi menunjukkan bahwa terdapat 23 siswa (100\%) interpretasi tinggi, 0 siswa $(0 \%)$ interpretasi tidak tuntas. Selain itu berdasarkan KKM yang telah 
ditetapkanmenunjukkan bahwa siswa yang mencapai nilai lebih dari 69 jumlah 23 siswa sehingga KKM secara klasikalnya dinyatakantuntas.

Belajar mencapai 82,60\%.NilaiGainnya adalah 0,67 yang diinterpretasikan sedang dengan nilai rata- rata siswa.Karena pada siklus II secara keseluruhan siswa telah mencapai KKM yang telah ditetapkan oleh pihak sekolah, maka penelitian ini tidak dilanjutkan lagi pada siklus berikutnya dan hanya sampai pada siklus II.

\section{Hasil Belajar Siswa Kelas VII ${ }^{\mathrm{C}}$ SMP Muhammadiyah 1 Kota Ternate Pada Materi Operasi Bilangan Bulat Dengan Menerapkan Model Problem Based Learning}

Hasilbelajar pada tes awal sebelum diterapkan model pembelajaran berbasis masalah (Problem based learning). Terlebih dahulu peneliti memberikan tes awal pada hari Kamis tanggal 5Januari 2017 dengan memberikan 4 item soal untuk mengukur kreativitas matematis siswa terhadap materi operasi bilangan bulat. Data yang diperoleh dari tes awal dilaksanakan pada hari Kamis tanggal 5Januari 2017 terdapat 19 siswa tidak tuntas atau $(82,60 \%)$, sedangkan yang tuntas terdapat 4 siswa dengan ketuntasan belajar klasikal pada tes awal adalah (17,39\%) disini nampak masih banyak siswa yang mengalami kesulitan dalam menyelesaikan soal operasi bilangan bulat. Sehingga peneliti menerapkan model pembelajaran berbasis masalah (Problem based learning).

Setelah diterapkan model pembelajaran berbasis masalah pada siklus I hari Senin tanggal 9 Januari 2017, saat itu pula observasipun berlangsung yang diamati oleh observer dengan mengisi lembar observasi kegiatan belajar mengajar, disini terlihat bahwa ada juga siswa yang belum dapat menyelesaikan soal dengan benar, hal ini dapat dilihat dari hasil tes pada siklus I, sebanyak 18 siswa $(78,26 \%)$ tidak tuntas sedangkan 5 siswa $(0,0 \%)$ tuntas.

Dari hasil tes siklus I belum mencapai KKM hal ini mengakibatkan bahwa siswa kelas VII ${ }^{\mathrm{C}}$ SMP Muhammadiyah 1 Kota Ternate belum mencapai KKM yang ditetapkan, yaitu 69. Oleh karena itu, penerapan model pembelajaran berbasis masalah (Problem based learning)dilanjutkan pada siklus II.Pada siklus I, siswa sangat pasif dalam pembelajaran menjadi aktif pada siklus II. Setelah proses pembelajaran selesai, maka dilakukan tes siklus II diperoleh peningkatan yang signifikan pada hasil belajar siswa kelas VII $^{\mathrm{C}}$ terhadap materi operasi bilangan bulat. Terjadinya peningkatan yang signifikan disebabkan karena siswa sangat paham dengan materi yang telah di ajarkan. 
Dengan menggunakan model pembelajaran berbasis masalah (problem based learning), siswa dituntutaktifdalam proses pembelajaran.

Setelah dilakukan refleksi pada siklus II ternyata siswa sudah menguasai materi operasi bilangan bulat. Siswa kelas VII ${ }^{\mathrm{C}}$ SMP Muhammadiyah 1 Kota Ternate mencapai ketuntasan belajar yang berjumlah 19 siswa atau KKM secara klasikalnya adalah 82,60\% sehingga KKM yang ditetapkan oleh sekolah telah tercapai, yaitu 69 oleh sebab itu, siswa sudah mencapai ketuntasan belajar, sehingga penelitian ini dilakukan sampai pada siklus II saja.

\section{Peningkatan Kreativitas Matematis Siswa Kelas VII ${ }^{\mathrm{C}}$ SMPMuhammadiyah 1 Kota Ternate Setelah di Terapkan Model Pembelajaran Berbasis Masalah (Program Based Learning) Pada Materi Operasi Bilangan Bulat.}

Dengan diterapkan model pembelajaran berbasis maslah (Problem based learning) telah terjadi peingkatan kreativitas matematis siswa, pada siklus I diperoleh hasil tes siswa 61,39\% dan belum mencapai KKM yang telah di tetapkan di sekolah SMP Muhamadiyah 1 Kota Ternate. Tetapi setelah di lanjutkan pada tes siklus II diperoleh hasil tes siswa $87,43 \%$, dari hasil tes ini telah terjadi peningkatan yang signifikan dan mencapai KKM yang telah di tetapkan pada sekolah tersebut.

Hasil penelitian ini diperoleh bahwa:

a. Tingkat kreativitas matematis siswa setelah diterapkan model problem based learning. Hal ini sesuai dengan Siswono (Ahmad, Duskri dan Amalia, 2015: 40) menyatakan bahwa kreativitas merupakan produk berpikir kreatif. Berpikir kreatif merupakan suatu proses yang digunakan ketika mendatangkan atau memunculkan suatu ide baru. Hal tersebut menunjukkan bahwa kemampuan berpikir kreatif siswa sangat penting untuk menjadi perhatian guru. Hal ini sesuai dengan Ridwan (Nafiah dan Suyanto, 2014: 135), menunjukan bahwa telah diterapkan model problem based learning siswa dapat mencapai 82,8\%. Dalam hal ini juga sesuai dengan Lambestus (Asikin dan Cahyaningsih, 2015: 283), menunjukan bahwa terdapat perbedaan antara kemampuan berpikir keativitas matematis siswa dengan menggunakan model problem based learning dan model konvensional, dimana kemampuan berpikir kreativitas matematis siswa lebih meningkat dengan menggunakan model problem based learning. 
b. Pembelajaran berbasis masalah kemampuan berpikir siswa yang betul-betul dioptimalkan yang melalui proses kerja kelompok atau tim-tim yang sistematik. Hal ini sesuai dengan Arjana (Syahruddin, Pudjawan dan Sariadi, 2014: 23), yang menunjukan bahwa model pembelajaran berbasis masalah dapat meningkatkan hasil belajar siswa sehingga mencapai tingkat penguasan $80,3 \%$. Dalam hal ini juga sesuai dengan Suhardjono (Wahyudi dan Subhanarrijal2014: 286), menunjukan bahwa hasil belajar siswa lebih baik dalam mengunakan model problem based learning dengan mencapi nilai 86,86 dan telah memenuhi target atau interpretasi tinggi.

\section{KESIMPULAN}

Berdasarkan Hasil Penelitian dan Pembahasan, maka Peneliti dapat Menyimpulkan:

1. Tingkat kreativitas matematis siswa kelas VII ${ }^{\mathrm{C}}$ SMP Muhammadiyah 1 Kota Ternate setelah diterapkan model problem based learning mencapai 87,43\%, dan dikatan tuntas

2. Penerapan model problem based learning dapat meningkatkan kreatvitas matematis siswa kelas VII ${ }^{\mathrm{C}}$ SMP Muhammadiyah 1 Kota Ternate dengan intrepretasi tinggi $87,43 \%$.

\section{DAFTAR PUSTAKA}

Ahmad, A., Duskri, M. dan Amalia, Y. 2015. Penerapan Model Eliciting ActivitiesUntuk Meningkatkan Kemampuan Berpikir Kreatif Matematis Dan Self ConfidenceSiswa SMP. Jurnal Didaktik Matematika, Vol (2), No 2, 40.

Asikin, M. dan Cahyaningsih, R. 2015. Komparasi Kemampuan Berpikir Kreatif Matematissiswa Menggunakan Pembelajaran Matematika Humanistik Dan Problem Based Learning Dalam Setting Model Pelatihan Innomatts. Jurnal Nalar Pendidikan. Vol (3), No 1, 283.

Kusmaryatni, N. Dkk. 2014. Implementasi Model Pembelajaran Berbasis Masalah Untuk Meningkatkan Aktivitas Dan Hasil Belajar IPA. Journal MIMBAR PGSD Universitas Pendidikan Ganesha Jurusan PGSD, Vol (2), No 1, 3.

Nafiah, N.Y. 2014. Penerapan Model Problem-Based Learning Untuk Meningkatkan Keterampilan Berpikir Kritis Dan Hasil Belajar Siswa.Jurnal Pendidikan Vokasi. Vol (4), No 1, 135. 
Rahman, A., Their, S dan Al A'raf, A. 2015. Keefektifan Penerapan Model Pembelajaran Kooperatif Dengan Pendekatan Scientific Dalam Pembelajaran Matematika Di Kelas VIII SMP Negeri 2 Majene. Jurnal Daya Matematis, Vol (3), No1, 63-64.

Sunaryo, Y. 2014. Model Pembelajaran Berbasis Masalah Untuk Meningkatkan Kemampuan Berpikir Kritis Dan Kreatif Matematik Siswa SMA Di Kota Tasikmalaya. Jurnal Pendidikan dan Keguruan, Vol (1), No 2, 43.

Saefudin, A.A. 2012. Pengembangan Kemampuan Berpikir Kreatif Siswa Dalam Pembelajaran Matematika Dengan Pendekatan Pendidikan Matematika Realistic Indonesia (PMRI).Al-Bidāyah, Vol (4), No 1, 40. 